\title{
The Japanese Hospital in Broome, 1910-1926. A harmony of contrasts
}

\author{
${ }^{1} \mathrm{P}$ Stride, ${ }^{2} \mathrm{~A}$ Louws \\ ${ }^{1}$ Senior Lecturer, University of Queensland School of Medicine, Brisbane, Australia; ${ }^{2}$ Medical Student, Monash University Medical School, \\ Victoria, Australia
}

\begin{abstract}
The Japanese Hospital in Broome remains the only hospital in Australia's history predominantly staffed, controlled and funded by a linguistically, culturally and geographically alien nation. Initially the proposal, challenging prevailing attitudes, was bitterly opposed by the white community, but the hospital became respected thanks to Dr Tadashi Suzuki, the hospital's first doctor, and his successors' clinical skills and compassion.
\end{abstract}

KEYWORDS Broome, Western Australia, decompression sickness, diving, Japanese Hospital, pearls

DECLARATION OF INTERESTS No conflict of interests declared
Correspondence to P Stride

University of Queensland School of Medicine

Brisbane

Queensland 4012

Australia

e-mail pjostride@gmail.com

\section{INTRODUCTION}

The remote town of Broome on the north-west coast of Western Australia is close to the Asian cities of Jakarta, Singapore, Kuala Lumpur and Bandar Seri. When commercial quantities of Pinctada maxima, the largest pearl oyster, were discovered in the late 19th century, opportunists from neighbouring countries and Australia poured into Broome.'

Broome developed rapidly as a multinational community, dominated by white Australians of European origin, with racial and social strata and tensions but commercial interdependence. Asians outnumbered Europeans and the Japanese became the most influential, largely thanks to their skilled pearl divers. ${ }^{2}$ The Chinese dominated the merchant arena and other Asian nationalities crewed the pearl luggers. The diverse nationalities had functional commercial relationships but separate social lives linked to families back home. Racial jealousy and intolerance occasionally triggered friction. The Australian indigenous people were bottom of the social order, sometimes being banned from the town, subjected to brutality, imprisonment in chains, and their women used for prostitution. Their treatment was considered worse than that of African slaves in the USA before the Civil War. ${ }^{3}$

The Japanese funded, built and staffed (apart from the nursing staff) their own hospital. Although there was initially strong opposition from the white community, the hospital and doctors became appreciated largely thanks to the clinical skills, availability and compassion of Dr Tadashi Suzuki, the hospital's first doctor, and his successors. ${ }^{4}$ In the absence of extant hospital records or the Japanese doctors' diaries, information is predominantly derived from contemporary newspapers.

\section{BROOME - THE BEGINNING}

Prior to the European influx, several groups of Australian indigenous people occupied the Dampier peninsula, enjoying the rich resources of land and sea, intermarriages and cultural links, and their spiritual connection to the land expressed through their creational mythology. The collision with Western society destroyed their culture. ${ }^{4}$

In I86I, Pinctada maxima, the world's largest known pearl oyster and the only species to produce South Sea pearls, were discovered in Roebuck Bay, on the northwest coast of Western Australia. Initially the small settlement of two stores and a few houses, with a native well for water by the mosquito-ridden mangroves, had no road or rail links to the south and supplies and communication arrived irregularly by sea. Mother of pearl shell was initially collected by wading in shallow water, then by diving up to 10 fathoms (18 metres) without equipment. In the 1860s and 1870s Aboriginal women were kidnapped, forced to dive naked for pearl shells during the day, and kept on board overnight for sexual services, until the shallow waters were depleted and diving equipment with skilled divers became necessary. ${ }^{3,4}$ Roebuck Bay was proposed as a pearl industry port in 1879. The government surveyor-general and famous explorer, John Forrest, chose an adjacent site near three wells by Dampier Creek for a new township in 1883, and town blocks were available from 1886. The State's Governor, Frederick Broome, was unimpressed when the shanty town was named after him! $!^{3,45}$

\section{THE TOWN}

Broome, a town in which lanes lined with noodle stalls and opium dens, and the slum dwellings of hawkers and prostitutes were more reminiscent of Asia than Australia; and where pearl shell mattered 
more than human life. Tales of murder, rape, theft, brutality and treachery are found side by side with courage, honesty, and pioneering vision. ${ }^{6}$

Within 20 years, Broome developed a huge pearling industry, further stimulated by the new international submarine telegraph cable passing through Broome. ${ }^{1,4}$ Stores and hotels were established, including the famous Roebuck Hotel. Fabulous fortunes were made by a few astute pearlers and businessmen when the value of mother of pearl escalated in global financial capitals, and Broome was acknowledged as providing the best pearls for international markets. The remote town required self-sufficiency, hence a mutual dependency developed across divides of class, wealth, colour and nationality. The pearling industry required skilful and willing divers and Japanese migrants proved best at this hazardous job. Senator Staniforth Smith described the town population: 'Here were gathered together from all quarters of the earth the most heterogeneous collection of nations, creeds, languages and races I ever saw, a veritable ethnological museum'. ${ }^{7}$

In I90I the population of Broome was I358; consisting of Malays, Filipinos, Japanese, Europeans and other nationalities including Timorese. ${ }^{8}$ That year, approximately 250 boats harvested almost 1000 tons of pearl shell worth over $\notin 100,000 .^{8}$ The Australian Government Immigration Act commenced the white Australia racist policy, which persisted until abolished by in 1973.9 A written dictation test, in any European language, individually selected by a migration officer to keep out 'undesirables', restricted migration. ${ }^{10}$ However, the Japanese Consul felt this should not apply to his country stating:

The Japanese belong to an empire whose standard of civilisation is so much higher than that of kanakas, negroes, Pacific Islanders, Indians, or other Eastern peoples that to refer to them in the same terms cannot but be regarded in the light of a reproach"

The Japanese divers, merchants and other workers and their families going to Broome were exempted from this act.

\section{THE JAPANESE INFLUENCE IN BROOME}

The Japanese people rapidly integrated into Broome society, although not as social equals of the white community. Though called Chinatown today, two-thirds of the population of the original historic heart of Broome in Carnarvon Street were Japanese. The Asian quarter became very overcrowded and unhygienic; its 20 acres contained all the requirements of the pearling industry; from merchants and restaurants to brothels, from pearl cleaners and sail makers to opium dens. ${ }^{4} \mathrm{Dr}$ Graham Blick, the local government doctor, notified the council in the 1912 health report of the hazards of many people sleeping on verandahs, and toilets adjacent to kitchens and sleeping spaces.'

The Japanese and other Asians attracted both racial criticism and support. In August $1913 \mathrm{Mr}$ X Donnelly, of the Dock, Rivers and HarborWorkers Union, complained that the Chinese and Japanese monopolised retail, banking and financial, and medical concerns in northern Western Australia. ${ }^{2}$ A subsequent editorial refuted these points, listing white bakers, tailors and retailers working in the area.

Half the patients in the Broome Hospital were Japanese..$^{13}$ They felt there was a lack of cultural medical attention, and sought to build a Japanese Hospital with a Japanese doctor. ${ }^{4}$ By 1909 they had adequate funds for a Japanese doctor's salary, expenses and return fare pending exemption from the Immigration Act. They sought an appropriate doctor, purchased and renovated a suitable house, and sent money to the Japanese Consul-General in Sydney who interceded with the Federal Government for support. ${ }^{14,15}$

Nine hundred Japanese people are buried in the Broome Japanese cemetery, many dying young while working in the pearl industry. ${ }^{3}$ An obelisk commemorates 40 Japanese sailors and divers who died when 4I pearling luggers were lost in the April 1908 cyclone. Thirty-three of the graves are dated 1914, when the bends caused many painful deaths. ${ }^{2,16}$

\section{THE JAPANESE HOSPITAL: THE BEGINNING}

The controversy of a Japanese doctor in a Japanese hospital provoked nationwide comments. Dr Paton, the District Medical Officer, wrote to the Principal Medical Officer in Perth on 17 September 1910. He reported that the local health board had declined an application for a Japanese Hospital as the Government Hospital provided free accommodation for all, that a beriberi ward was created at local request, and that there would be inadequate revenue for the local doctor or the hospital in Broome without the Japanese admissions. The PMO replied in agreement. ${ }^{13}$ The Broome Municipal Council and the Pearlers' Association protested to Prime Minister Alfred Deakin by telegraph and letter for the above reasons, and also because they objected to having 'a full-fledged medical practitioner of an alien race'. Arthur Male believed the Japanese 'had always hitherto received the best of medical attention' for free, and they feared similar demands from the Chinese and Afghan populations. ${ }^{17,18}$

Mr Uyeno, the Consul-General for Japan, gave the official Japanese viewpoint that only a Japanese-speaking doctor could understand the symptoms of the many nonEnglish speaking Japanese pearlers in Broome. They had no complaint about the government doctor. Uyeno said 
that he had already employed an eminent medical graduate from Kyoto University, who was about to leave Japan for Broome and stated:'I have no reason to expect that a properly qualified Japanese doctor will be excluded from an Australian hospital where there is a special need for his services'. ${ }^{19}$ That statement was reported in several states, ${ }^{14}$ repeating the opposing arguments, noting that 'the prospect of seeing a Japanese doctor practicing among his fellow-countrymen in Broome seems to have deeply shocked the very tender susceptibilities of the white population in that salubrious town' and concluded that the opposition demonstrated racial prejudice. A totally different perception comes from an interview in the 1950s with a Japanese gentleman, Saumi, who migrated to Australia in 1895 aged 19 and reached Broome in 1907.

The many deaths among our colleagues was (sic) a source of deep concern to us and for many years we sought to introduce a Japanese doctor and set up our own hospital. There was in Broome a general hospital and an infectious diseases hospital - both run by the state. There was nothing wrong with the facility, but the vital point was the doctor and he was an utter quack. He was so bad that his nickname was Dr Murder. If anyone got malaria or beriberi he would clap them in isolation and that would be that. What was the treatment? Well, most of them died. More than half the graves in the cemetery were of patients admitted under these circumstances. We had no choice but to try and establish our own hospital. ${ }^{4,20}$

This unsubstantiated defamatory statement given some 40 years later, perhaps related to the period of Blick's declining health, must represent a prevalent Japanese perception.

The Anglo-Japanese Treaty of Alliance of 1902, supporting mutual interests against China and Russia, ensured friendship between the UK, Japan and Australia. ${ }^{21}$ Military information was shared, Australian Navy representatives were welcomed to Japan to observe the Russo-Japanese war, and the Japanese were respected as a decent, orderly, efficient, reliable nation..$^{22}$ The recognition of Japanese medical qualifications in the UK finally quashed opposition. The PMO replied to Dr Paton: 'No valid objection can be made to such a medical man's registration if he possesses British qualifications'. ${ }^{3}$

On 3 August 1909, Mr Littleton Groom, External Affairs Minister, ${ }^{23}$ announced in the House of Representatives a 2-3 year exemption certificate under the Immigration Restriction Act for a qualified Japanese doctor to attend the Broome Japanese community. The initial selection, Dr Kitiwaki, withdrew due to the illness of his mother and was replaced with Dr Tadashi Suzuki.. ${ }^{24}$

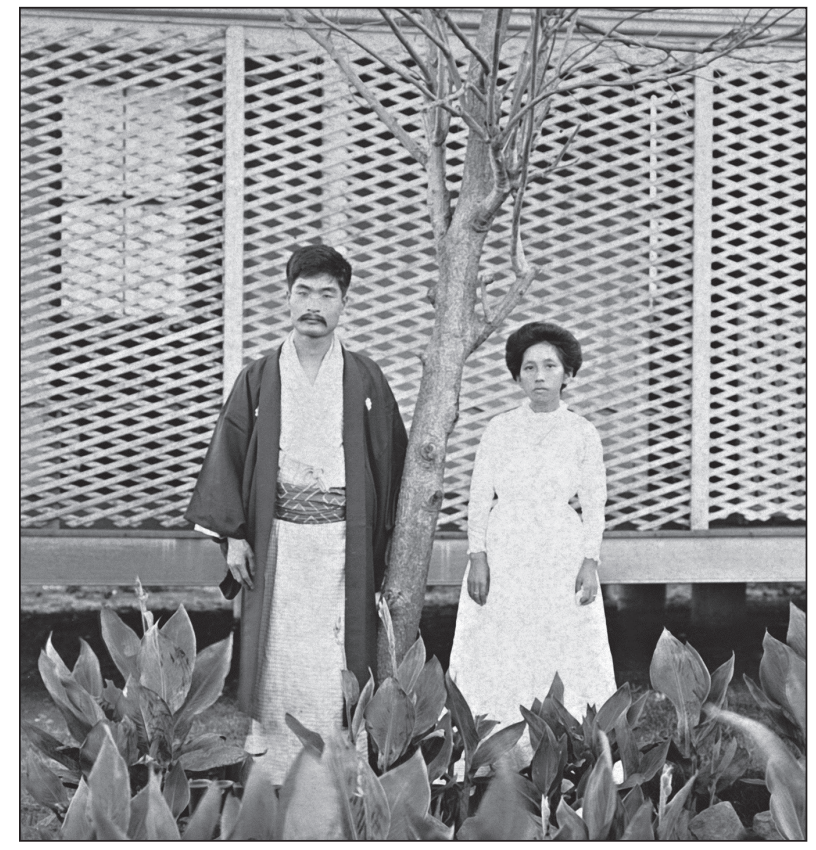

FIGURE I Dr and Mrs Tadashi Suzuki, circa 1912

\section{THE ROLE OF DR BLICK - GOVERNMENT MEDICAL OFFICER I900-1912}

Dr Graham Blick, the Broome government medical officer, was pivotal in Japanese health issues. As the sole medical practitioner and a published expert on the medical complications of diving, he cared for the Japanese population including the pearl divers; he opposed the concept of the Japanese Hospital, but subsequently worked with Dr Suzuki. Blick, born in 1868 in Oxfordshire, graduated in law, medicine and pathology from Oxford University before migrating to Australia in early 1900.5 He was a leading member of Broome society with other responsibilities including Justice of the Peace, acting Resident Magistrate and President of the Central Board of Health.

An outbreak of smallpox hit Broome in 1904. Blick quarantined the pearling lugger Sultan, because one of the crew had a resolving rash; though well and previously vaccinated, Blick suspected chickenpox, but cautiously isolated the sailor until smallpox became apparent..$^{25}$ The second smallpox outbreak inside three months occurred when five other cases on a pearling lugger followed; fortunately all survived. ${ }^{26}$ Blick suspected imported clothing as the source unrelated to the Sultan case. The Colonial Secretary and $\mathrm{Dr}$ Lovegrove, the principal medical officer, requested Blick isolate four smallpox cases ashore and observe the fifth onboard. ${ }^{27}$ Five days later Blick said the isolated cases were appropriately treated..$^{28}$

In 1909 Blick published a seminal paper ${ }^{29}$ detailing eight years' experience of diver's paralysis in the world's largest pearling centre, when knowledge of the bends 


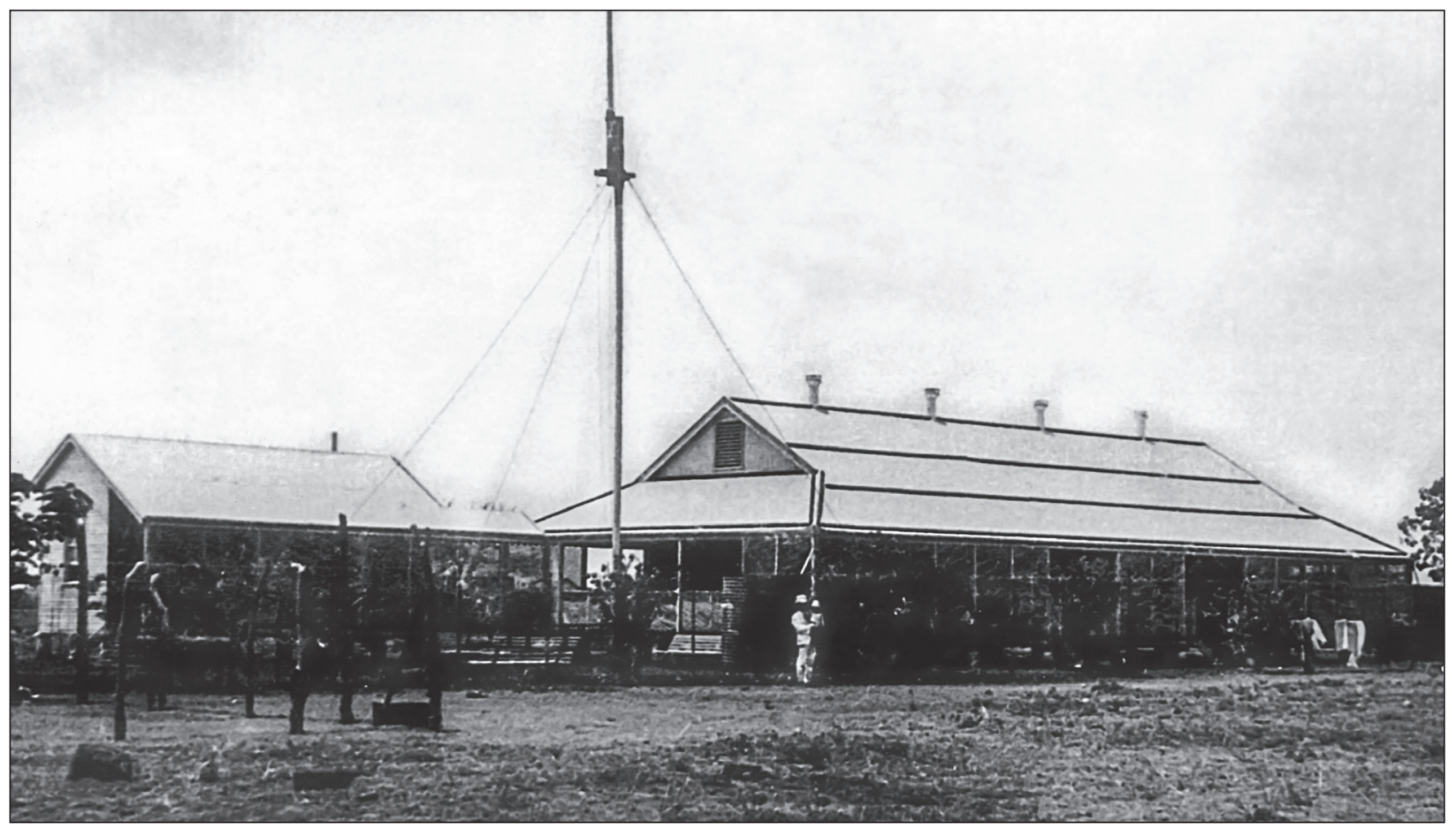

FIGURE 2 The Japanese Hospital in Broome

was limited. Joint pains after decompression were first recorded in the 1830s. ${ }^{30}$ In 1869 Dr Alphonse Jaminet was the first physician to experience and describe decompression paralysis when working on Eads Bridge, St Louis, USA. ${ }^{31}$ Gray's 1893 text of neurological disease records only 16 known autopsies on decompression victims in the USA. ${ }^{32}$

Pearl shell was gathered from depths down to 25 fathoms and hand wheels pumped air into helmets. Divers experienced overpressures of 20 to $50 \mathrm{lb}$ per square inch and Blick advised slow ascension. Pearling luggers several hundred kilometres offshore were some days sailing from medical attention. Blick performed 60 autopsies on decompression fatalities, perhaps currently the largest series in the world, and these invariably detected congested hearts, lungs and major vessels with blood, and partial disintegration of the spine with internal haemorrhages. He believed scurvy caused the higher frequency of haemorrhages from the bends between September and March, and recommended increased vegetable consumption to reduce cases.

Blick also managed 140 survivors noting more motor than sensory neurological defects with varying severity of paralysis, most marked in the legs, associated invariably with urinary retention. Eleven survivors subsequently died, eight from cystitis and septicaemia caused by unclean catheters, an ongoing problem today despite modern antibiotics. Most recovered, often slowly, and about $10 \%$ were left with slight paresis, particularly in the anterior leg muscles.
By early 1912, Blick's health was deteriorating. Shaw thought a lacerated finger accidentally sustained during an autopsy on a Japanese diver had caused a chronically infected wound. In late 1912 Blick returned to England for surgery, perhaps on his chronically infected finger, perhaps for cancer, but the disease was widespread, and he died in November leaving a widow and four children in Broome. ${ }^{33}$

Two locums, Dr Paton, then Dr Shaw, ${ }^{3}$ worked briefly before Dr Goldstein replaced Blick as medical quarantine officer at Broome. Goldstein performed the autopsy on Sanders, the last fatality among the white divers. ${ }^{3} \mathrm{Dr}$ Arthur Haynes served in Gallipoli, before becoming Broome District Medical Officer for 25 years. $^{5}$

\section{SPECTRUM OF DISEASES IN BROOME}

The conditions found in early 20th century Broome also occurred among the Japanese Hospital patients, particularly diving problems. Prevalent diseases included: infant and maternal mortality, smallpox, whooping cough, tuberculosis, rheumatic fever and venereal diseases, drowning, heart disease, infections, suicides or diving incidents, beriberi and leprosy. Many lugger crews were lost to unpredictable storms and cyclones.

\section{Beriberi}

Beriberi, or thiamine deficiency, was common at sea and among the Asian community. The resident medical officer reported 72 deaths and 489 non-fatal cases over the three year period 1910-1912. ${ }^{3}$ The aetiology of beriberi was debated, one school blamed consumption of 
unpolished rice while others, including Blick, blamed an infection and prevented further spread with a public hospital isolation ward. ${ }^{3}$ However Blick's 1909 article recognised that an appropriate diet prevented beriberi.. ${ }^{29}$

\section{The bends}

Once the shallow areas were depleted of pearls, divers had to go deeper. The early pearling luggers owners, crew and divers knew little of the hazards of deep prolonged diving, therefore decompression sickness caused frequent incapacitation or very painful deaths. Some divers died before ascension or were unrecognisably compressed. Returning bodies to Broome for burial was impractical in the tropics, so many were buried at sea or on nearby islands.

The pathophysiology of decompression sickness became slowly understood. The British Admiralty developed tables with recommended ascension rates, but not all pearlers and divers followed these, though they were strongly endorsed by DrYakuo Harada..$^{34}$ The Broome death register between 1896 and 1915 recorded 104 I deaths. Of these, $94 \%$ were male, $75 \%$ were between the ages of 20 and 40 and most of them were Asian, some having only recently arrived. Of the male deaths, 228 (23\%) were attributed to drowning, $373(38 \%)$ to heart disease (though many of these were probably drownings) $24 \mathrm{I}$ (25\%) to infections and 47 (5\%) to suicides or homicides. ${ }^{35}$

Heinke, the British submarine manufacturing company, installed a recompression chamber in Broome in October 19/4. Initial utilisation occurred on 19 February 1915 on a Japanese diver paralysed in 10-15 metres of water four days earlier. ${ }^{36} \mathrm{~A}$ lumbar lesion caused paralysis and anaesthesia of his legs. Following four hours recompression and gradual decompression therapy, sensation returned and he ambulated with a stick. ${ }^{37}$ The decompression chamber did not prevent deaths, as more severe cases died at sea days from treatment. A total of 29 died in 1913,33 in 1914,21 in 1915 and 19 in 1916, with nine treated by recompression in 1915$16{ }^{36}$ Its last recorded use in Broome Hospital was in 1954. Although subsequently abandoned on Broome rubbish dump, it was located, restored and placed in the Broome Historical Museum in 1991. ${ }^{36}$

\section{Infant mortality and obstetrics}

Many graves in the Broome cemetery reveal the high infant mortality rate and the risks of childbirth in a remote centre a century ago. In 1912 the Japanese Hospital was the only site of obstetric services in Broome as there was no public hospital birthing unit. ${ }^{38}$ In July 1912 the Minister for Works visiting Broome was disappointed by the birth of a white Australian baby in 'an Asiatic controlled institution' and strongly recommended a Government maternity unit be established. ${ }^{39}$

\section{Influenza}

Many residents were affected by a severe influenza outbreak in 1919. Although 58 people were reported to be delirious there were no deaths. A number of pearling luggers were in port with infected and incapacitated crews and many Asians queued by torchlight outside the Japanese hospital for medication. ${ }^{40}$

\section{Leprosy}

Leprosy was unknown in the Australian indigenous people prior to the 19th century. Well known in ancient Asia, it reached Europe in the last millennium BC, peaked there in the Middle Ages, before progressively declining. The last recorded death in Scotland was on Shetland in 1798. ${ }^{41}$ Leprosy was probably introduced into Australia from endemic Asian countries rather than from Europe. ${ }^{42}$ Leprosy was diagnosed occasionally in the time of the Japanese Hospital. Between 1900 and 1920, 22 cases were notified across northern Western Australia. ${ }^{42}$

In 1912 Dr Blick and Dr Suzuki diagnosed a mixed-race Broome woman's skin disease as advanced leprosy. ${ }^{43} \mathrm{Dr}$ Goldstein reported another case of leprosy in 1913; the patient was briefly isolated before discharge into the community. ${ }^{3}$

In Cape Leveque, north of Broome, the disease became much more prevalent over the next 50 years. Official notifications among the indigenous people in Broome were 0 between 1898 and 1920, three between 1921 and 1930, then 70 between 193I and 1976. ${ }^{42}$ The majority were managed in the Derby isolation hospital $200 \mathrm{~km}$ away.

The RMOs reported to the Road Board on 19 June 1923, that the Broome Hospital matron had contracted leprosy. In June 1936, the State Member of Parliament noted that leprosy cases, predominantly indigenous people, were arriving in Broome Hospital which lacked isolation facilities. A review of $36 \mathrm{I}$ indigenous people in Broome that year found eight to have leprosy. ${ }^{42}$

\section{Other infections and the indigenous people}

Between 1896 and 1915, the Broome deaths register largely ignored the Aboriginal people. No Aboriginal deaths were recorded between 1896 and 1901, and only 45 between 1896 and 1915. However the non-immune indigenous population suffered high rates of morbidity and mortality by the 1870 s from infectious diseases such as smallpox, whooping cough, tuberculosis, rheumatic fever and venereal diseases introduced by white explorers and settlers. Hundreds were said to have died during a smallpox epidemic in $1866 .{ }^{3}$ Eighteen indigenous women, some as young as 16, had died of venereal diseases according to a witness in Roth's Royal Commission in $1905 .^{3}$

Dr Walter Roth enquired into venereal disease and other aspects of Aboriginal health by obtaining evidence 
from police, pastoralists, priests and pearlers. ${ }^{44} \mathrm{He}$ noted 'The boats' crew suffer a good deal from venereal disease and the loss of their labour is severely felt by the pearlers. Much has been made of the incidence of loathsome disease and the reality was that mariners the world over had a higher incidence and for all the usual reasons.'

The avoidance of major outbreaks of typhoid, other forms of dysentery and hepatitis A in a crowded tropical environment, is considered a testimony to the competence of Drs Blick, Suzuki and Paton plus the council health inspectors. ${ }^{34} \mathrm{~A}$ white male died of enteric fever in the Japanese Hospital under Suzuki's care in November 1912. An outbreak of fever had occurred among visitors to the Asiatic quarter attributed to the district's limited hygiene. ${ }^{3,45}$

\section{Trauma}

Violence simmered just below the surface in this frontier multi-ethnic society. The Government and Japanese doctors provided therapy, performed postmortems and appeared as expert witnesses in court.

Mark Liebglid was murdered in Broome on 30 August 1905. Blick's autopsy detected multiple facial abrasions, three skull fractures, and a fractured finger, presumably caused by a blunt, heavy instrument. Water in the lungs and stomach indicated that drowning caused death, though the skull wounds were potentially fatal. Charles Hagen, an Englishman, and Pablo Marquez and Simeon Espada, Filipinos, were all found guilty and subsequently hanged for murder. ${ }^{46}$

In 1914 a fight occurred between some 500 Japanese and 200 Koepangers (Timorese). After five hours of sporadic violence, 8-9 Japanese and 7-12 Koepangers were injured, two seriously. All were treated in the two hospitals, presumably the Japanese attending their own establishment. ${ }^{47}$

A fight between a Japanese man and a Koepanger precipitated a race riot in Broome in December 1920. The state premier, advised the Prime Minister, Billy Hughes, on 21 December 1920 outlining events and requesting a warship's presence. ${ }^{48}$ Sir Francis Newdegate, the state Governor of Western Australia, wrote to the Governor-General on 22 December 1920 also suggesting that a visiting naval vessel would calm the town and the local suggestion to deport the Japanese, particularly with the pearling industry recession. The Prime Minister announced the dispatch of HMAS Geranium to maintain order. ${ }^{49}$ The Riot Act was read and the police restored order, supported by white male civilians. Six Japanese were admitted to their hospital with two fatalities and five Koepangers were admitted, also with two fatalities. ${ }^{2}$

\section{THE JAPANESE HOSPITAL}

The hospital was constructed on the corner of Napier and Lochlan Streets. The structure has been removed, and no hospital records are extant.

\section{Nursing staff}

Sisters of St John of God were essential in establishing the hospital and caring for its patients. Sister Antonio, born in Ireland in 1859, had nursed in the goldfields of Western Australia and recruited volunteers, predominantly Irish nursing sisters, and sailed for the Beagle Bay mission north of Broome in 1907. After a year they transferred to Broome where they depended upon community support for accommodation, and financial support. ${ }^{50}$

The Catholic Sisters and the Japanese Buddhists respected each other's culture and rapidly established a working relationship. The Sisters purchased essentials from the Japanese stores and the young Japanese children attended the Catholic School rather than the state school. ${ }^{16}$ In 1911 the Japanese Community provided funds and a builder to construct a Catholic School, and the Japanese community attended the Sisters' evening classes in English, book-keeping and music. This challenging bond achieved by the Sisters across language, culture and religion greatly assisted the wider community's acceptance of the proposed Japanese Hospital with a Japanese doctor. ${ }^{51}$ When the Japanese wished to open their own hospital, the controlling Broome Roads Board demanded the employment of European nurses. At Dr Suzuki's request the Sisters agreed to undertake the nursing and Sister Michael Power became the first matron, enabling the newly named 'Maza-Antoni' hospital to open. ${ }^{4}$

The Sisters provided dedicated care for minimal remuneration in the Japanese Hospital from 1910 until it closed in 1928, even assisting one Japanese doctor with English. ${ }^{4}$ The local Japanese community and Uyeno requested additional Japanese nurses, but after correspondence between the interested parties, the Sisters blocked this proposal as they were not prepared to be subordinate nursing staff..$^{52}$

Sister Mary Ignatius arrived in Broome in 1912, and covered the night-shift reportedly carrying her mattress from the convent to the Japanese Hospital each night. ${ }^{5}$ In January 19/2, Sister Immaculate Leahy, died aged 25 from either typhoid or smallpox, while nursing an epidemic at the hospital. The Japanese community erected a marble Celtic cross in the cemetery in her memory. ${ }^{3,4}$ Saumi noted the care of the nuns greatly reduced the number of deaths from beriberi and malaria, and that the success of the Japanese doctors improved relations between the Japanese and Australian doctors. ${ }^{20}$ 


\section{THE FIRST THREE YEARS OF THE JAPANESE HOSPITAL UNDER DR SUZUKI}

Dr Suzuki arrived with his wife on 15 January 1910 aboard the Koombana, with a permit to practise in Broome from 1909-1912. The council recognised his professional skill and approved his application for a three year extension. ${ }^{3,16} \mathrm{~A}$ Broome Chronicle editorial described him as a highly qualified practitioner whose unquestioned ability has been amply demonstrated in Broome, and expressed anxiety that his departure would lead to a white doctor securing a monopoly. ${ }^{53}$

Blick strongly opposed the renewal of Suzuki's permit. He wrote to Hugh Mahon, federal member for Broome, claiming that a petition signed by about 100 citizens of Broome supporting Suzuki was misleading, that some white men "had fallen so low as to allow their women to be attended by the Japanese doctor', that this caused the local attitude that a 'coloured man was good as white', and that the Japanese doctor signed pearling crews off sick with 'some little unsoundness' clearly insignificant in Blick's opinion. Blick believed Broome had changed over 12 years, and was now 'absolutely ruled by the Japanese Club'. Blick noted the Japanese doctor 'attends to white men who may have been offended by some act of mine' suggesting his communication skills had caused some of his problems. Blick was clearly a strong believer of the white supremacist attitude widely prevailing then, stating 'Blacks can never equal white'. To Suzuki's credit, Blick's four-page letter, which he preferred to be kept private, did not imply any professional incompetence. ${ }^{54}$

By early 1912, Blick's deteriorating health left Dr Suzuki doing a double workload, including running the Government Hospital. The Nor'West Echo stated that patients attending the Japanese Hospital were assured of skilled medical care and competent nursing under the guidance of Dr Suzuki and the other staff. ${ }^{3,55}$

Dr Suzuki performed the highly significant autopsy on William Webber in the Japanese Hospital in June 1912.3.56 Webber, a 32-year-old Englishman, was a celebrity in the UK for his diving feats. He led the group who successfully raised sunken Spanish treasure in Tobermory Bay in the Scottish Hebrides. He led the group of British ex-Royal Navy divers who came to Broome to demonstrate their superiority over the Japanese divers but failed disastrously. They were much less skilled at finding pearls shells. On 7 June, Webber had a day's diving with repeated short ascension times. At the end of the day while relaxing on deck, he clutched his leg and fell briefly unconscious. He refused a decompression period and then deteriorated. His left side became increasingly cold, he lapsed back into a semi-conscious state, his skin turned livid and he died. Suzuki confirmed death from the bends. His diving equipment was in perfect working order.
The autopsy revealed a haemorrhage around the knee joint, the effect of air bubbles rupturing the joint space, some beads of gas in the coronary veins, and froth within the chambers of the heart, indicating a mixture of blood and released gas. Most of the white population of Broome attended his funeral with much sadness. Webber's death supported the impression that British divers were less skilled at pearling than the Japanese and more expensive to employ.

Dr Suzuki returned to Japan in 1914 , to specialise in paediatrics. The newspapers noted that he had developed 'a remunerative business, not only among his compatriots but also among the whites', while resident in Broome, probably a compliment to his clinical skills. ${ }^{57} \mathrm{Dr}$ Suzuki subsequently had a distinguished career, being appointed Professor of paediatrics at Kyoto Empire University in 1925, and founding a medical journal, the Oriental Journal of Diseases of Children. He died in 1933. ${ }^{34}$

\section{SUBSEQUENT JAPANESE DOCTORS}

\section{Yakuo Harada 1914-19/8}

Dr Harada replaced Dr Suzuki on 14 May 19/4. ${ }^{58} \mathrm{~A}$ critically ill woman needing urgent surgery was admitted to the Japanese Hospital in January 1915, but in the absence of the Government Medical Officer, Harada would not operate unsupported. The lady was too sick to travel south by ship, and too poor to pay the fare. Unfortunately the outcome of this story and the lady's ethnicity remain unknown. The newspaper recommended finding a white doctor as the white inhabitants were left 'to the tender mercies of the Japanese medico' who was denied access to the local Government Hospital. ${ }^{59}$ This is surprising as Suzuki had regular access rights to the government hospital, particularly during Blick's absence. Harada supervised therapy with the recompression chamber from 19 February 1915 onwards. ${ }^{36}$

His skills were recognised in a letter to the local paper 'his devotion to the duties of his position is so well known, that there is no need to do other than to make grateful recognition of his capable service...he is badly overworked. ${ }^{60}$ When Dr Harada left on 27 June 1918 it was reported that he 'gave every satisfaction to his clients who much regret his departure'. ${ }^{61}$

\section{Dr Tsukano Tojojiro |9|8-1921}

Dr Tojojiro was a Japanese Imperial University graduate. Correspondence to the Japanese consul general in Sydney advised that the Japanese Hospital averaged 25 outdoor and 20 indoor patients. ${ }^{62}$ The debate about employing a senior Japanese nurse occurred during his residency. Tojojiro supervised treatment during the 1919 severe outbreak of influenza. ${ }^{40} \mathrm{He}$ welcomed the visiting Governor, Sir Francis Newdegate, and Mr Colebatch, the Education Minister to the Japanese Hospital in May 
1920.63 Tojojiro expressed concern about the safety of the track to the Japanese Hospital as patients were badly shaken up by the drive, though the outcome is unknown. ${ }^{64}$

\section{Dr Masuyama Masogoshi 192I-1924}

The Broome Chronicle noted that the arrival of $\mathrm{Dr}$ Masogoshi would enable $\mathrm{Dr}$ Haynes to take a holiday and a Mrs J Joston recorded her thanks to the Sisters of St John of God, Dr Haynes and Dr Masuyama for their kind attention to her late husband..$^{65}$

\section{Dr Michio Sakai 1924-1927}

The Japanese consul-general applied for Dr Sakai's appointment to Broome, and customs department correspondence records his arrival in Broome in November 1924, and departure from Australia on 7 March 1927. ${ }^{.6}$

The hospital closed in about 1928, when the new plastics industry reduced the demand for mother-of-pearl, and when international relations between the Anglosphere and Japan had cooled coincident with increasing Japanese sea power and possible hostilities.

\section{THE JAPANESE HOSPITAL - LATER DEVELOPMENTS}

The dispensary was moved to Gantheaume point in 1934 according to unreferenced Broome museum sources. The next year, the Beagle Bay Mission purchased the empty Japanese Hospital, still a fine building, intending re-erection at Beagle Bay, as a hospital for the ailing indigenous population. The relocation was delayed because a severe cyclone had damaged the mission. By 1939 it had not yet been moved and its fate is obscure. ${ }^{67}$

The Japanese Hospital's success encapsulated the professional interdependence of Broome's diverse racial groups, despite the dominant white minority's initial resistance and white supremacist attitude, and regardless of simmering mistrust among different nationalities, largely thanks to the socially and professionally skilled Japanese doctors and the previously unrecognised high standard of medical training provided in Japanese medical schools over a century ago. Norman ${ }^{34}$ concludes the Japanese doctor was by 1925 an established community member, esteemed by his European colleagues with whom he worked closely and, as the majority of pearlers agreed, to the benefit of the community. ${ }^{16} \mathrm{Dr}$ Frank Wallace, appointed District Medical Officer to Broome in 1936, wrote of '...an excellent working relationship between the Japanese and European doctors in the town and we called each other in to give second opinions or to help each other at operations'. ${ }^{34}$ At a medical and nursing professional level, it was a harmony of contrasts.

\section{ACKNOWLEDGEMENTS}

Pictures courtesy of the Sisters of St John of God, Broome

\section{REFERENCES}

I Burton V. General History of Broome. Broome, WA: Pindan; 2000. p.6-15.

2 Edwards H. Port of Pearls. Kalamunda, WA:Tangee Publishing; 2009. p.52

3 Bailey J. The White Divers of Broome. Sydney: Pan Macmillan; 2001. p.20-292.

4 Sickert S Beyond the Lattice: Broome's Early Years. North Fremantle, WA: Fremantle Arts Centre Press; 2003. p.21-129.

5 Shaw C. The History of Broome's Street Names. Broome,WA: Pindan; 200I. p.I4-44.

6 Broome and the Kimberley. http://www.broomeandthekimberley. com.au/20I I/03/06/broome-history-culture (accessed 2I/5/20I5).

7 Smith S. The West Australian Pearl-Shelling Industry. Perth, WA: V.K. Jones \& Co; 1903.

8 Lawton K. A History Walk Down Johnny Chi Lane. Broome, WA: Pindan; 2003. p.25-29.

9 Yu S, Wei C. The Story of the Chinese in Broome. Broome, WA: Pindan; 1999. p.I0-II.

10 Immigration Restriction Act 190I. http:/www.naa.gov.au/ collection/a-z/immigration-restriction-act.aspx (accessed 2l/5/20I5).

II Commonwealth Parliamentary Papers, no 2, 190I-2. Melbourne. p.855

12 Asiatics - The North-West. Sunday Times, Perth 17 August 1913.
13 State Records Office Western Australia. Health 1910 2364.000-00 I

14 The Japanese Doctor. Singleton Argus 3I August 1909.

15 National Archives of Australia. Series no AI, Control Symbol 1925/5576, Barcode 43700 'Japanese Doctor at Broome (Yoshido Harada and Toyojuro Tsukano)[and other doctors]'. Letter. Archie Male to Uyeno. 7 August 1909.

16 Jones N. Number 2 Home, A story of Japanese pioneers in Australia. North Fremantle, WA: Freemantle Arts Centre Press; 2002. p.49109.

17 State Records Office Western Australia. Health 1909 ANI 20/4 Acc 1003, Item 5, 1909.

I8 Japanese doctor for Broome. Protest by white residents. Western Australian 30 July 1909.

19 An Alien Doctor. Clarence and Richmond Examiner 5 August 1909.

20 Sissons DCS. The Japanese in Australia 187/-1946. (unpublished presentation, ANZAS Conference, Perth 1973, State Library of Western Australia).

2I Cavendish R. Anglo-Japanese Treaty of Alliance. http://www. historytoday.com/richard-cavendish/anglo-japanese-treaty-alliance (accessed 21/5/20I5)

22 Oliver P.Allies, Enemies and Trading Partners: Records on Australia and the Japanese. http://guides.naa.gov.au/allies-enemies-tradingpartners/index.aspx (accessed 2I/5/20I5).

23 Daily News (Perth) 4 August 1909. 
24 National Archives of Australia. Series no AI, Control Symbol 1925/5576, 9/I 1404, Barcode 43700 'Japanese Doctor at Broome (Yoshido Harada and Toyojuro Tsukano)[and other doctors]'. Letter. Uyeno to Dept External Affairs. 23 September 1909.

25 Smallpox at Broome. Outbreak on Steamer Sultan. The West Australian 3 May 1904.

26 Smallpox at Broome. Four cases reported. The West Australian 16 July 1904.

27 Smallpox at Broome. Another case reported. The West Australian 18 July 1904.

28 Smallpox at Broome. Further precautions being taken. More lymph required. The West Australian 23 July 1904.

29 Blick G. Notes on diver's paralysis. BMJ 1909; 2: 1795-8.

30 Acott $\mathrm{C}$. A brief history of diving and decompression illness. $\mathrm{S}$ Pacific Underwater Med Soc J 1999; 29: 98-109.

31 Jarcho S. Alphonse Jaminet on Caisson Disease. Am J Cardiol 1968; 21: 258-60.

32 Gray LC. A Treatise on Nervous and Mental Diseases: For Students and Practitioners of Medicine. Philadelphia: Lea Brothers; 1893.

33 Broome's Medical Officer Dies in London. The West Australian 19 November 1912

34 de B JE , Norman GV. A Pearling Master's Journey. Burwood,Victoria: BPA Print Group Pty Ltd.

35 Gracey M, Spargo R. Deaths in Broome,Western Australia I883 to 1994. Aust N Z J Public Health 1996; 20: 506-II.

36 Thurston S. The first Broome recompression chamber. S Pacific Underwater Med Soc J 2004; 34: 94-100.

37 Nor'West Echo 27 February 1915.

38 Member for Cue. Northern Times 8 June 1912.

39 The North-West. Visit of the Minister for Works. The West Australian 22 July 1912.

40 Influenza at Broome. Coloured populace in terror. Western Mail 20 November 1919.

4I Manson P. Tropical Diseases. London: Cassell and Co; I898. p.383422

42 Davidson W. Havens of Refuge. A History of Leprosy in Western Australia. University of Western Australia Press; 1978

43 Leprosy at Broome. An editor's find. At loggerheads. Northern Times 28 September 1912.

44 Report of the Royal Commission on the condition of the natives http://bit.ly/IINcnrz (accessed 2I/5/20I5).

45 Broome Chronicle 30 November 1912.

46 The Broome Murder.Accused before the criminal court. Evidence for the prosecution. The West Australian 8 November 1905.

47 Pitched battle at Broome between Japanese and Koepangers. Sunday Times I3 December 1914.
48 The Broome riots. A search for arms. Town strongly patrolled. Meeting of citizens. Some strong resolutions. The West Australian 23 December 1920

49 The Broome Riots, warship on the way. Western Argus 28 December 1920.

50 Heroes in Faith - Sister Antonio, Parts I and 2. Catholic Diocese of Broome, Kimberley Community Profile, 2013, October, Issue 5 and December, Issue 6

5I The historical relationship between Taiji and Broome (museum exhibition in Taiji, Japan), Personal communication, Sisters of St John of God, Broome,

52 National Archives of Australia. Series AI, Control symbol 1919/2649 Barcode 374/8 Admission of Japanese Nurse for Broome Hospital.

53 Japanese Doctor. Broome Chronicle 22 June 1912.

54 National Archives of Australia. Series no AI, Control Symbol 1925/5576, Barcode 43700 'Japanese Doctor at Broome (Yoshido Harada and Toyojuro Tsukano)[and other doctors]'. Letter. Blick to Mahon. 18 May 1912.

55 Hospital. Nor'-West Echo 7 September 19/2.

56 White diver's death. Paralysis the cause. The West Australian I5 June 1912

57 Japanese Doctor. Northern Times 20 June 1914.

58 National Archives of Australia. Series no AI, Control Symbol 1925/5576, Barcode 43700 'Japanese Doctor at Broome (Yoshido Harada and Toyojuro Tsukano)[and other doctors]'. Letters. Uyeno to Atlee Hunt and Hunt to Japanese consul. 30 January 1919 and 6 February 1919.

59 Labor White Australia advocates. Sunday Times 24 January 1915.

60 Nor'-West Echo 22 January 1916

6I Broome Chronicle 25 May 1918.

62 National Archives of Australia. Series no AI, Control Symbol 1925/5576, Barcode 43700 'Japanese Doctor at Broome'. Letter to S. Shimuzu, Consul General for Japan.

63 Capital of the North West. Sovereign and Ministerial party at Broome. The West Australian 19 May 1920.

64 Broome Chronicle II December 1920.

65 Thanks. Broome Chronicle 20 May 1922

66 National Archives of Australia. Series no AI, Control Symbol 1925/5576, Barcode 43700 'Japanese Doctor at Broome (Yoshido Harada and Toyojuro Tsukano)[and other doctors]' Customs Dept Letter re Dr. Sakai.

67 Caring for the natives. The West Australian II December 1935 